\title{
A Systematic Mapping of BIM and Digital Technologies for Architectural Heritage
}

\author{
Mansuri, L.E. ${ }^{1}$, Patel, D.A. ${ }^{1}$, Udeaja, C. ${ }^{2}$, Makore, B.C.N. ${ }^{3}$, Trillo, C. ${ }^{3}$, Awuah, K.G.B. ${ }^{3}$, \\ and Jha, K.N. ${ }^{4}$ \\ ${ }^{1}$ Sardar Vallabhbhai National Institute of Technology (SVNIT), Surat, India \\ 2 London South Bank University, London, UK \\ ${ }^{3}$ University of Salford, Manchester, UK \\ ${ }^{4}$ Indian Institute of Technology Delhi, India
}

\begin{abstract}
Purpose

Across the architecture, engineering and construction industry, the application of Building Information Modelling (BIM) as a digital technology for architectural heritage is becoming increasingly relevant. However, scholarly research on the application of BIM for architectural heritage is still in its infancy stage and the research gaps and future directions of this research area are still unclear. This paper therefore aims to fill this gap by using a systematic \& robust review using a mixed-method approach to show the gaps of research for BIM and architectural heritage and point to new directions for future works.
\end{abstract}

\section{Design/methodology/approach}

The study includes a quantitative scientometric analysis and mapping and a qualitative study. A total of 354 articles related to BIM and architectural heritage were analyzed using a combination of quantitative and qualitative tools. The qualitative study consists of a systematic literature review supported by data collected from stakeholder and training workshops on digital technologies and BIM for Heritage.

\section{Findings}

Findings from this study reveal the gaps in the field of Heritage and BIM research according to retrieved articles from different countries and journals. Furthermore, emerging domains for future research were identified and these included: As-built modelling and 3D reconstruction; Conservation, preservation and management; Documentation; Maintenance and restoration; Virtual technology and Simulation.

\section{Originality/value}

The common research challenges were identified as an integrated outcome of the findings revealed from the scientometric mapping and qualitative review and resulted in key BIM and heritage research priority recommendations relevant to researchers within this field.

Date of Acceptance: 26/05/2021 


\section{INTRODUCTION}

Building Information Modelling (BIM) has warranted increasing attention over the past decade in the field of Architecture, Engineering and Construction (AEC) (Volk et al., 2014). BIM in AEC industry has been extensively utilised to cope with the complexity and difficulty of managing multiple activities and contractors across the globe (Ahuja et al., 2016). More recently, the benefits of using BIM have been progressively recognised as a suitable digital technology in the architecture heritage sector also known as HBIM (Heritage Building Information Modelling). In current conventional practice, nonavailability of documentation, drawings, and specifications of materials and other technical information of historic buildings results into time and cost overrun of their maintenance and rehabilitation projects (Gursel et al., 2009). BIM plays a critical role in the heritage sector in minimising those challenges by efficiently support historic information management, design and build decisions resulting in the production of sustainable and inclusive heritage assets (Pocobelli et al., 2018; Historic England, 2017; Rocha et al., 2020; Volk et al., 2014). By incorporating high-quality digital survey datasets, HBIM represents the appearance of the existing historic fabric and allows the exploration and complex analysis of several applications such as conservation planning, maintenance, heritage management, and interpretation. Parallel to this interest in HBIM is a growing discourse recognising the crucial role of cultural heritage in achieving sustainable development (Bala, 2012; Carlisle and Lee, 2016; Daele et al., 2016; Myers, 2016; Shah, 2016; Petti et al., 2020). Of the 17 finalised Sustainable Development Goals, one of those, Goal 11, centres on a pledge to "make cities and human settlement inclusive, safe, resilient and sustainable" and includes a series of 11 targets, each with politically negotiated indicators (United Nations, 2016). Under goal 11 is an important indicator for cultural heritage: target 11.4 "strengthen efforts to protect and safeguard the world cultural and natural heritage" (UN-Habitat, 2018). Digital technologies play a significant role to achieving this global target (Mansuri and Patel, 2021).

Although BIM for heritage has gained interest at an international level, the existing research on its application is still in its infancy. Works done to date are sparse and therefore it is unclear what the gaps of research are and what future directions should be taken for researchers within the AEC sector to achieve better results and minimise the challenges. Aiming to fill this gap, this study adopts a systematic mixed method approach, incorporating quantitative scientometric mapping and qualitative thematic analysis by targeting three objectives. This paper explores the latest BIM based developments in the architectural heritage field discourse to identify gaps in present practices and to explore emerging domains of research and recommend the research directions for future work of applying BIM in architectural heritage. The benefit of conducting a detailed global review of various studies on heritage building information modelling allows for a broader and holistic perspective towards new research and application of BIM in architectural heritage. 


\section{RESEARCH METHODOLOGY}

This study adopts a mixed-method systematic review approach (Harden and Thomas, 2010). According to Petticrew and Roberts (2008), systematic reviews have been widely used in studies for the purpose of identifying gaps in the body of knowledge and exploring emerging trends where little research has been done. Previous authors in different fields have used mono-method manual systematic reviews approach but the mono-method approach is mainly biased and prone to problems of subjective judgment and interpretation (Harden and Thomas, 2010, He et al., 2017, Jin et al., 2019, Elghaish et al., 2020). The other systematic reviews include scientometric analysis and mapping in various field related to BIM (Hilal et al., 2019; Olawumi and Chan, 2018; Zhao, 2017). Consequently, the use of a mixed methods systematic review in synthesising literature on a topic such as BIM and digital technologies for architectural heritage allows for more objectivity and provides the potential "to enhance the depth and breadth of understanding" (Heyvaert et al., 2016). Mixed methods systematic review studies combine and apply quantitative and qualitative methods for integration and analysis of available literature on a topic to study the literature according to a systematic procedure, with the aim of overcoming the bias inherent in mono-method manual systematic reviews (Harden and Thomas, 2010, Jin et al., 2019). In line with the above approach, the research design adopted is a mixed-method systematic and robust review (see Figure 1) that integrates the quantitative tools using the scientometric technique and qualitative thematic literature analysis to investigate existing developments within the heritage BIM field and to identify research priority areas. The first stage is the literature search using the WoS and Scopus database (Section 3.1). Following this, a scientometric analysis was conducted and identified four specific data: (1) emerging research areas from keyword and cluster analysis, (2) contribution of countries, (3) influencing documents and (4) influencing sources and journals. Additionally, at this stage, a thematic analysis of the qualitative study was conducted (section 3.2). This includes selected literature from the scientometric analysis and data collected from stakeholder workshops. Two stakeholder workshops (face-to-face and virtual) were organized with the purpose of mapping and identifying the emerging domains in the field of BIM and digital technologies for heritage. Additionally as an outcome from the workshops, training sessions were organized on 3D mapping of heritage. The workshops were organized by an international interdisciplinary research project team based in India and the UK. This research project aims to shed light to the interplay between digital technologies, planning practice and tangible heritage conservation, by clarifying the dynamic among the three fields and their implications in the practice. The workshops were attended by a total of 140 participant stakeholders from local, national and international government, academia and industry.

The final stage of this paper is the presentation of the BIM and Heritage research priority recommendations based on the data findings from the scientometric analysis and qualitative study. The workflow of this study is illustrated in Figure 1 and discussed in the following sections. 


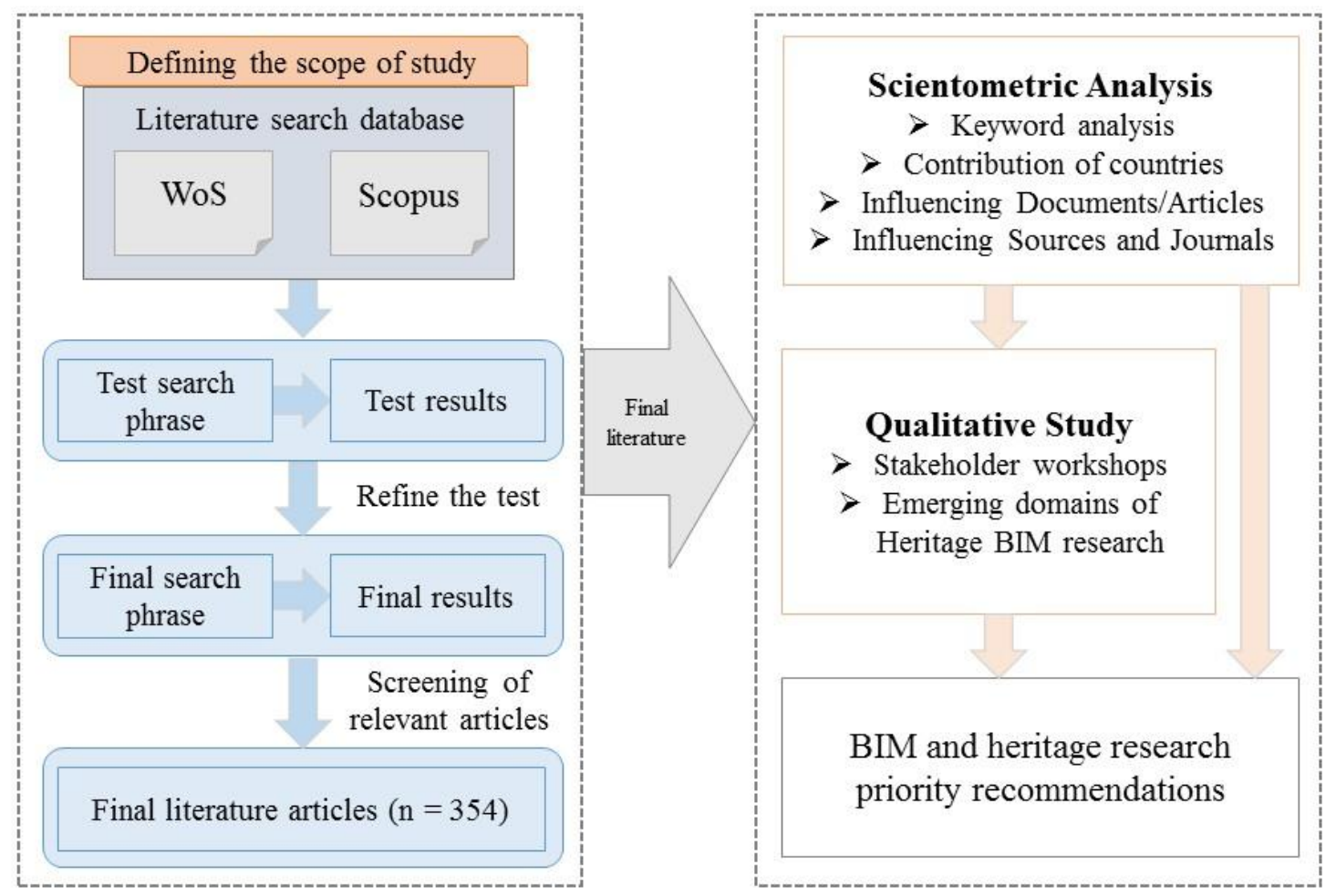

Figure 1: Workflow of study

The selection of a literature data is a crucial primary task in the systematic review process. The authors explored multiple databases for the literature data search and identified the Web of Science (WoS) and Scopus as a preferable database. This choice is further supported by a systematic comparative database review undertaken for scientometric analysis by Mingers and Leydesdorff (2015). The findings from their analysis found that the Web of Science (WoS) and Scopus database has a wide range of peer reviewed high-quality indexed journals and conference proceedings. The WoS and Scopus is preferred for collecting literature material for this study as it considers only peer reviewed articles and proceedings which have more impact values in the scientific community. Moreover, the WoS and Scopus databased includes most of the journals ScienceDirect and Emerald Insights. Only articles published in English language were analysed for this review. A test search phrase was formulated and used for the literature search focusing on searching the collection of materials containing articles related to BIM and heritage exclusively. 636 articles were identified focusing on either BIM or digital technology on heritage. It is also important to note that some of these articles originated from the medical field because BIM is also known as 'beam intensity modulation' in the medical science, and thus this has been delimited accordingly from the literature. To achieve more concise and relevant results in line with the aim of the paper, the final search phrase was refined with the following: "TS = (building information model* OR BIM 
OR digital* AND (heritage OR historic* OR as-built OR hbim))". TS represents the topic search and a fuzzy search denoted by ' ${ }^{*}$ ' which means the term may have some more relative characters than the given. The search resulted in, 462 articles. To further refine the result, a pre-processing criterion was applied to focus on articles related to engineering, construction and architecture and especially on architectural heritage, BIM and digital technology. After refining the final search results by manual screening, a total of 354 articles were collected for further analysis and review. This resulting sample size of 354 articles is suitable for the chosen methodology of this study as demonstrated by other studies with similar and even smaller sample sizes using the scientometric mapping technique (Golizadeh et al., 2019; Mahon and Joyce, 2015).

\section{FINDINGS}

\subsection{Findings from quantitative scientometric analysis and mapping}

Scientometric mapping is defined as the "quantitative study of science, communication in science, and science policy" (Hess, 1997), which measures the impact of keywords, countries, articles, journals, and understanding of scientific citations, mapping scientific fields and visualization of indicators for the use of policy making and management (Leydesdorff and Milojević, 2012). The scientometric analysis technique is useful for large and concise mapping and capturing of knowledge area by the means of identifying the trends and patterns using mathematical iterations and network representation. The scientometric analysis and mapping is being used to explore the directions of research for BIM in the architecture, engineering and construction (AEC) industry (Liu et al., 2019), BIM in structural engineering (Vilutiene et al., 2019) and BIM in facility management (Hilal et al., 2019). Numerous software packages are available for scientometric mapping, and visualization of bibliometric data. Cobo et al. (2011) carried out comparative analysis of nine popular science mapping tools, CiteSpace, Bibexcel, CoPalRed, Leydesdorff's Software, IN-SPIRE, NetworkWorkbench Tool, Sci2Tool, VOSViewer and VantagePoint. It was concluded that there is no specific tool that can be considered the best, however a thorough scientometric analysis within any field could be carried out using either any of the tools or combination of tools.

The Java based computer program "CiteSpace (5.3.R5 version (64-bit))" is easily available, free to use with a simple and easy user interface that works on any platform, providing graphical mappings between different scientific contributions. It also possesses all the required characteristics and features applicable to the WoS and Scopus database. Therefore, CiteSpace has been used to carry out scientometric analysis of data for this study. CiteSpace used to identify emerging terms and keywords, contribution from countries, most influential documents and most influential journals.

\subsubsection{Emerging research study areas from keywords analysis}

As part of this systematic review, an analysis of co-occurring keywords was conducted which reveals the emerging research study areas from the retrieved articles. Keywords are the comprehensive words which represent the content and concept of research articles. They serve as the reference in finding and understanding the theme and domain of that research article. Keywords reveal the development of a particular area of research 
over a time period (Zhao, 2017). Two types of keywords are extracted from the literature database records; (i) author keyword, and (ii) keyword plus. The author keyword is provided by the authors along with the articles, and the keyword plus is based on the journals research output classification. The CiteSpace utilizes both kinds of keywords to generate the network and the software merges similar keywords. The keyword analysis demonstrates the highly frequent keywords in the network as: "BIM" (frequency-112), "HBIM" (frequency-81), "cultural heritage” (frequency-75), "point cloud” (frequency-40), "architectural design" (frequency-35), "architectural heritage" (frequency-31), "photogrammetry" (frequency-28), "laser scanning" (frequency-27), "conservation" (frequency-23), and "architecture" (frequency-21). The network of co-occurring keywords and keyword clusters is shown in Figure 2 which contains 404 nodes and 1418 links. As shown in Figure 2, the research conducted showed the following observations, which are documented below:

- The high frequency keywords reflects the emerging and most researched area in the field of BIM and digital technology for architectural heritage.

- As per the experts of the stakeholder workshop of this study, the whole area of heritage BIM research can be divided into two major categories (i) process and (ii) digital tools. The top keywords represent processes such as conservation, preservation, documentation, management and refurbishment. Additionally, the keywords also reflect the most popular digital tools as laser scanning and photogrammetry.

- The figure illustrates that many research areas are isolated from the core network. This suggests that areas such as automated data processing, object recognition, algorithm, free/open source software, automation, restoration and augmented reality remain unexplored or research is on-going and not published.

- Fields such as accuracy assessment, ontology and decision making are isolated from current literature but these areas have huge potential for future development.

The keyword network provides the general overview of the emerging research areas in the field of BIM and digital technologies for heritage. Therefore, cluster analysis have been employed to detect the research pattern and hot areas of the research within the field. The keyword cluster analysis uses set of mathematical algorithms to generate the structured domains out of unstructured text information. In this research, cluster analysis is used to identify the emerging grouping of keywords that reflects the emerging areas of the research and development. The keyword terms was taken as the unit of cluster analysis in this study. CiteSpace automatically extracts the noun phrase from the keywords based on the long-likelihood rate (LLR) algorithm. In this study, total 16 clusters were identified and presented in the Figure 2. It is important to note that the automatic clustering can sometimes leads to misclassification of information. Therefore various trials and various algorithms were employed to get most relevant clustering in this study. This cluster analysis has further supported this research to qualitatively identify the emerging domains in the field. 


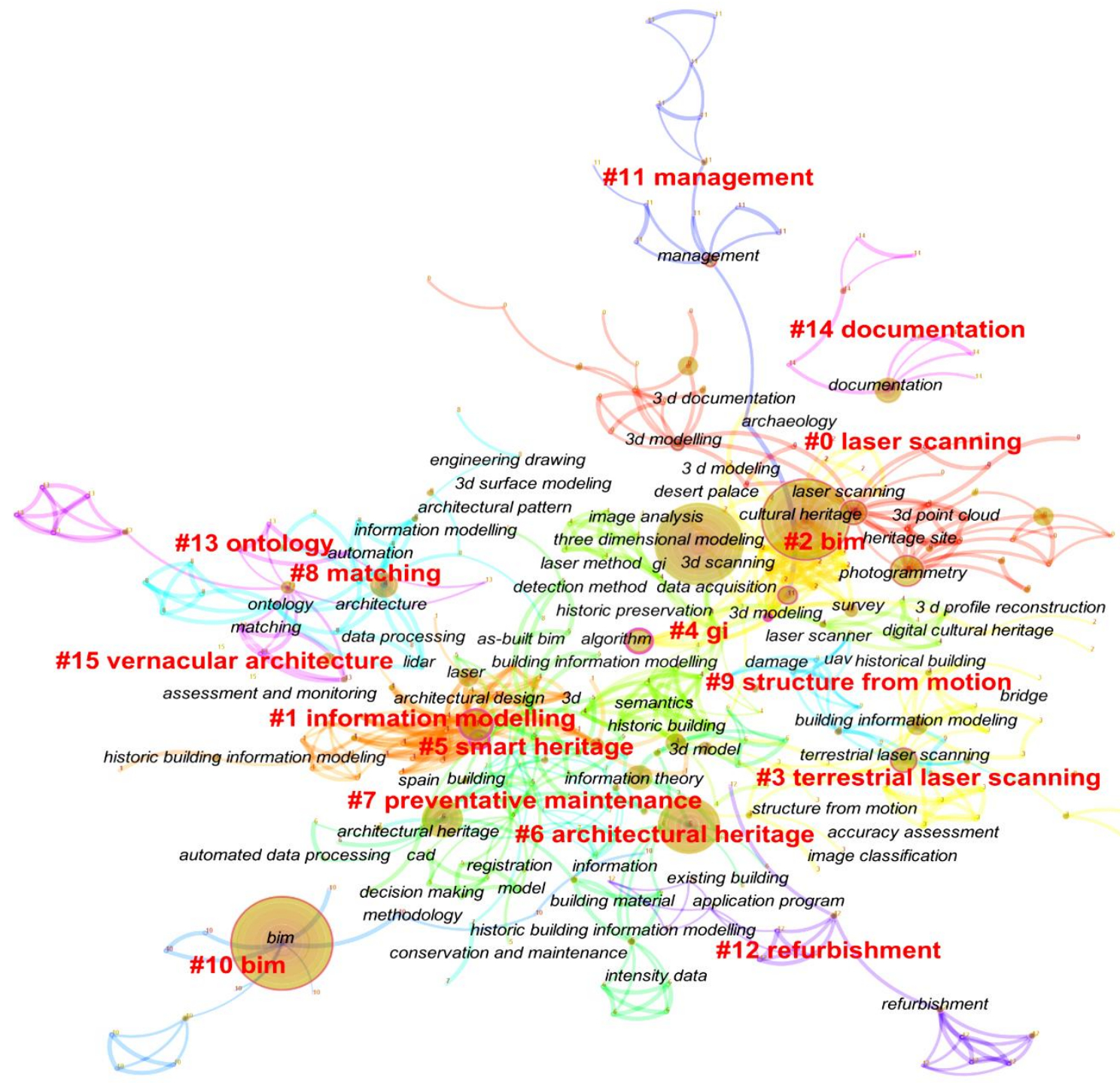

Figure 2 Network of co-occurring keywords and keyword clusters

\subsubsection{Contribution of Countries}

To map the collaboration pattern and to identify the most contributing countries in the architectural heritage research and practice, a collaboration network of countries was analysed. Figure 3 illustrates the network of countries as shown by 63 nodes and 63 links with each country representing a node and pattern of collaboration. A total of 36 major countries that are well known for research in BIM and digital technology for architectural heritage. The countries have more than 10 publications includes Italy (118 articles), Spain (45 articles), Peoples Republic of China (26 articles), England (UK) (23 articles), Portugal (17 articles), USA (16 articles), France (14 articles), Germany (14 articles), and Canada (12 articles). This analysis reveals that countries such as Scotland, Russia, Belgium, Taiwan, Cyprus, Bulgaria, Finland, South Africa, Singapore and Netherlands have weak collaborations with the main community and are connected with single links without having cross connection with other countries. Many Asian and African countries 
are absent in this collaboration though they have considerable number of UNESCO world heritage sites. India comes globally on sixth rank in terms of number of UNESCO world heritage sites and other national sites. Though, there is very weak collaboration of research with the main research community. The institutions and funding agencies need to focus on funding the digital technology research jointly with the main research community in order to have better technological exchange and collaboration.

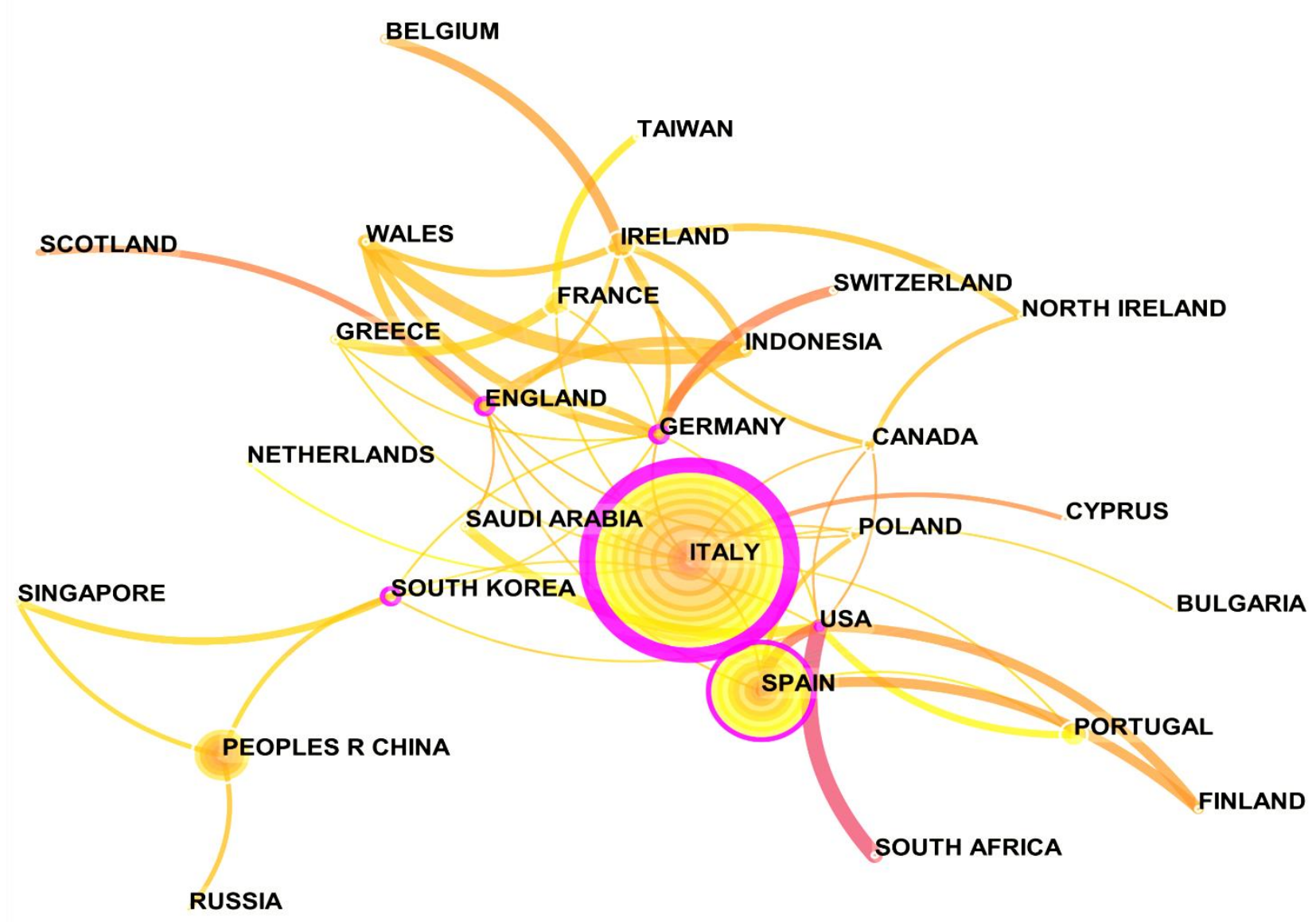

Figure 3 Collaboration network of countries

\subsubsection{Influencing Documents/Articles}

The document co-citation analysis is used to identify scholarship that has received peerrecognition indicated by citation patterns. For instance, when an author cites a particular document, the citation may indicate, among other properties, an idea or other resource that is important to the author's scholarly engagement with the cited text (Leydesdorff, 1998). Similarly, when a group of authors cite a common set of documents, these cocitations indicate documents that may contain concept symbols, the ideas, experiments, or methods that have received peer recognition, as indicated by their co-occurrence of citations (Small, 1978). Therefore, studies of how documents are cited together can assist researchers and practitioners in understanding important past contributions that were 
made within a field. The co-citation map of influencing documents/articles is presented in Figure 4 to visually display and analyse the cited relationship between documents. The top articles include: "Historic Building Information Modelling - Adding intelligence to laser and image-based surveys of European classical architecture" (Murphy et al., 2013), "Building Information Modeling (BIM) for existing buildings - Literature review and future needs" (Volk et al., 2014) and "Automatic reconstruction of as-built building information models from laser-scanned point clouds: A review of related techniques" (Tang et al., 2010).

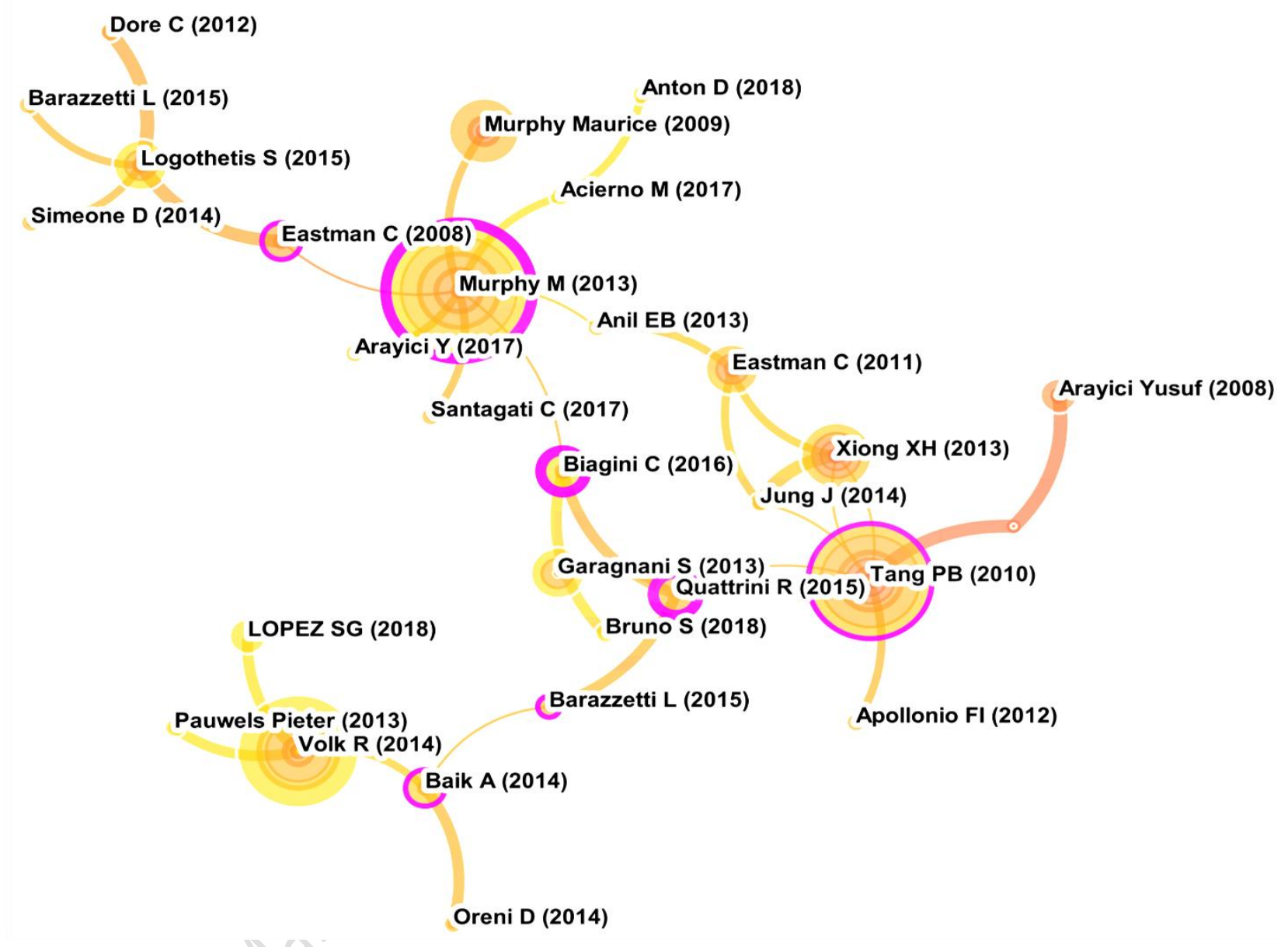

Figure 4 Network of influencing documents/articles

The document co-citation analysis also identifies the citation burst in the literature. The citation burst represents a citation of this document that has highly increased over a short period of time. It evidences that a particular publication is associated with a surge of citations meaning that the publication has attracted an extraordinary degree of attention from its scientific community and it is an indicator of a most active area of research. Evidence of this is shown from articles with strong citation bursts from articles exploring digital technologies and BIM for heritage such as the "Automatic reconstruction of as-built building information models from laser-scanned point clouds: A review of related techniques" (Tang et al., 2010) with the burst strength of 4.54, "Historic building information modelling (HBIM)" (Murphy et al., 2009) with the burst strength of 3.93 and 
the "Towards building information modelling for existing structures" (Arayici, 2008) with the burst strength of 3.56 .

\subsubsection{Influencing Sources and Journals}

The most influential journals have been identified through journal co-citation network mapping. The citations received by these journals are considered to be influential within the research body of BIM. These are the major sources of research articles which support the research and development in the field of BIM and digital technology for heritage. Attention should also be given to documents which are having high centrality. Centrality represents the number of connections of the node with the other nodes irrespective of directions of nodes. In other words, high centrality of any node means it has strong control over the network. In this case, "BIM Handbook: A guide to building information modelling for owners, managers, designers, engineers and contractors" has 0.11 centrality, "Advanced Engineering Informatics" has 0.10 centrality and "Journal of Cultural Heritage" has a centrality of 0.09 . These high centrality journals are the major intellectual sources which support the HBIM-based research.

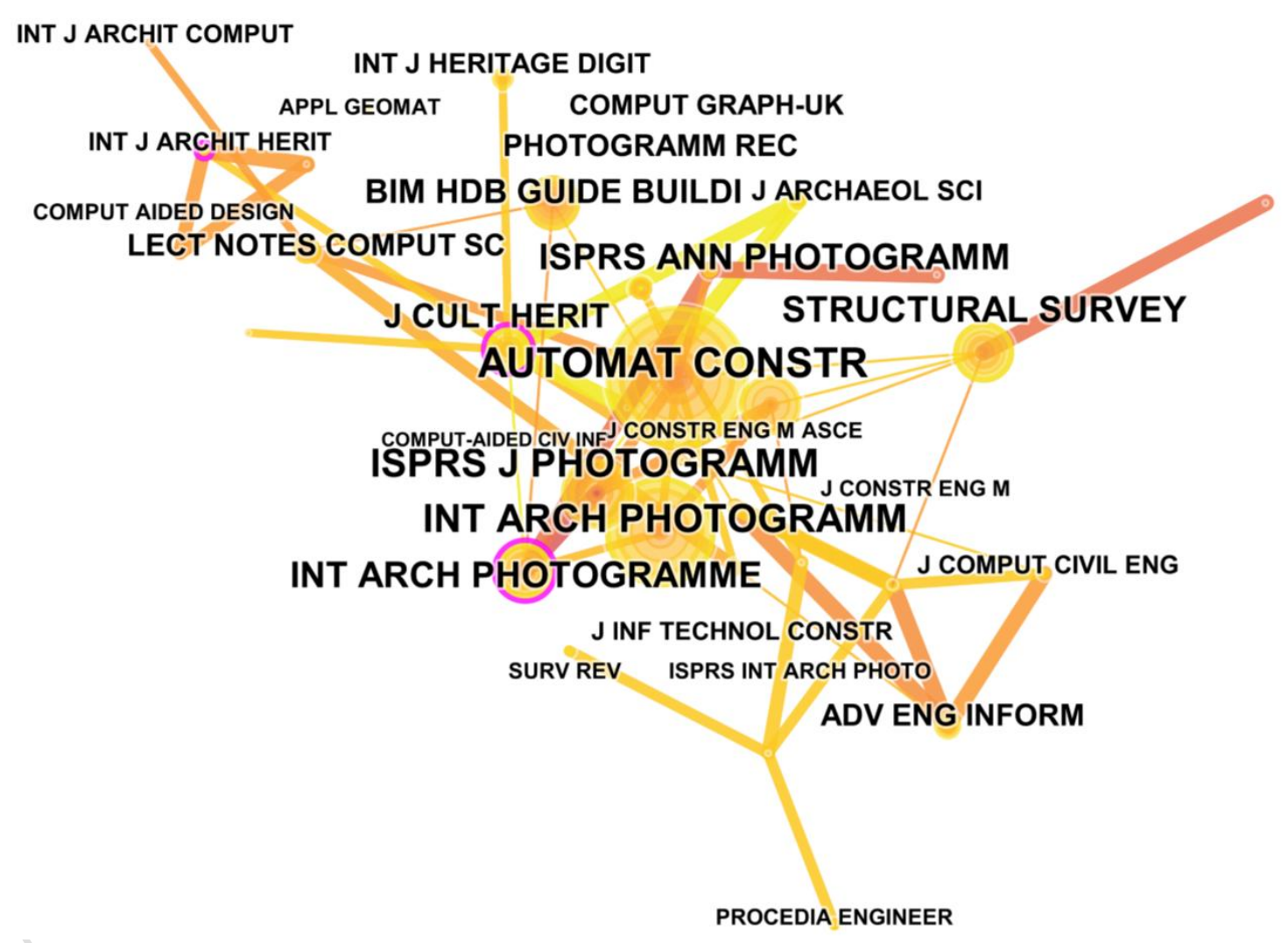

Figure 5 Network of journal co-citation

\subsection{Findings from the qualitative study: emerging domains of BIM and digital technologies for heritage}

Emergent areas are a basic building block of inductive approaches to qualitative social science research and can mean something akin to major aspects and dimensions of the phenomenon studied. The selected literature from the scientometric mapping detailed in 
the previous section has been analysed qualitatively to identify the emerging domains of research in the field of BIM and heritage. The identification of emerging domains were supported through the data collected from the three stakeholder workshops. Patterns were identified, analysed and interpreted from the literature and scientometric analysis and resulted in the identification of five emerging domains (major sub-areas) of the heritage BIM research. The keyword clusters were also the major base for identification these emerging domains. Among the five domains, the first and most important domain of research is the 'as-built modelling and 3D reconstruction' (Section 3.2.1), which is followed by 'conservation, preservation and management' (Section 3.2.2), 'documentation and mapping' (Section 3.2.3), 'maintenance and restoration' (Section 3.2.4), 'virtual technology and simulation' (Section 3.2.5). Table III demonstrates the mapping of articles with these five domains. The following sections present the data findings and discusses the developments in all the above emerging domains.

\subsubsection{As-Built Modelling and 3D Reconstruction}

This is the main domain of the heritage BIM research as the first step of any HBIM project is to convert physical assets of site/monument/structure into an as-built 3D model. In this connection, many researchers carried out extensive research on different methodologies and techniques of as-built modelling and 3D reconstruction. There was consensus within the workshops of the beneficial use of as-built modelling and 3D reconstruction for heritage preservation. However, there was acknowledgment of the lack of knowledge and understanding of the various technologies that can be used. Diverse challenges mentioned by stakeholders, particularly those in local authority and heritage charities and NGOs, included the lack of resources, funding and skills impacted the effective use of 3D technologies. Many stakeholders aligned with the growing momentum of embedding technology within heritage practices but lacked understanding of the finer details of how technology can be applied to current practices, what technology is best suited and how it can improve and impact current ways of working. When the research team discussed the HBIM process and modelling with specific examples of the integration of heterogeneous data, some stakeholders requested for further contextualisation. This highlighted the need for training and a mapping of the work done by stakeholders with the uses and benefits of HBIM. 3D reconstruction in particular was favoured for the promotional potential it has to market heritage assets to the wider community and improve the branding of historic areas and cities.

As per the database of the current study, articles focus on research and different applications of as-built modelling and 3D reconstruction of architectural heritage. For the feasibility of HBIM and development of a 3D model for complex architectural shapes, using terrestrial laser scanned (TLS) point clouds was frequently mentioned (Quattrini et al., 2015). However, as the literature analysis reveals, exclusively using laser scanning will not be enough to produce a 3D model. Xu et al. (2014) developed a 3D point cloud model with a camera-equipped unmanned aerial vehicle (UAV) and a TLS. A further advancement work by Jung et al. (2014), developed a semi-automatic methodology for large and indoor conditions to improve the productivity of as-built BIM. Rua and Alvito (2011) in their work, contributed tools for testing and analyzing theories and hypotheses 
for historical scenarios by 3D modelling. Manferdini and Galassi (2013) compared traditional topographic technologies with range-based (laser scanning) and photogrammetry and concluded that the combination of traditional topographic technologies and photogrammetry are more economical but they require high accuracy and skills. Dore and Murphy (2013) presented a plug-in for BIM software to generate semi-automatic digital heritage models from laser scan or photogrammetric.

For a better understanding of the present status of architectural heritage based on its history (timeline), Rodriguez-Gonzalvez et al. (2017) introduced the fourth dimension of time into 3D geometric modelling of real data which enables multi-temporal representation of a site. Xu et al. (2016) conducted investigation and synergetic use of UAV and TLS in the 3D reconstruction of cultural heritage objects. Rojas-Sola and de la Morena-de la Fuente (2018) produced 3D reconstruction of Betancourt's historical heritage using Computer Aided Design (CAD). Logothetis et al. (2017) illustrated the use of open source CAD tools to develop BIM that is able to manage 3D models of cultural heritage. Built to improve the accuracy of 3D models, Anton et al. (2018) developed an accuracy analysis of 3D modelling.

The analysis demonstrates that as-built modelling is still very much a manual process that requires further exploration into the potential of automation. Furthermore, there is a need for the development of awareness of the various methodologies and techniques of as-built modelling. As part of the research project and as an outcome from the stakeholder workshops, training workshops were organised for local researchers, heritage practitioners and students. These workshops were found to be an effective method to raise awareness of the technologies and to introduce targeted stakeholders to the skills needed for as-built modelling and 3D reconstruction. The workshops included a structured training of 3D mapping of heritage sites by using aerial photography captured by Unmanned Aerial Vehicle (UAV). The laser scanning of two monuments was also completed by the laser scanner as shown in Figure 6. A photogrammetry technique was used for developing a virtual tour of the heritage sites using the captured photographs. The laser scanned structures were converted into Building Information Model (BIM). 


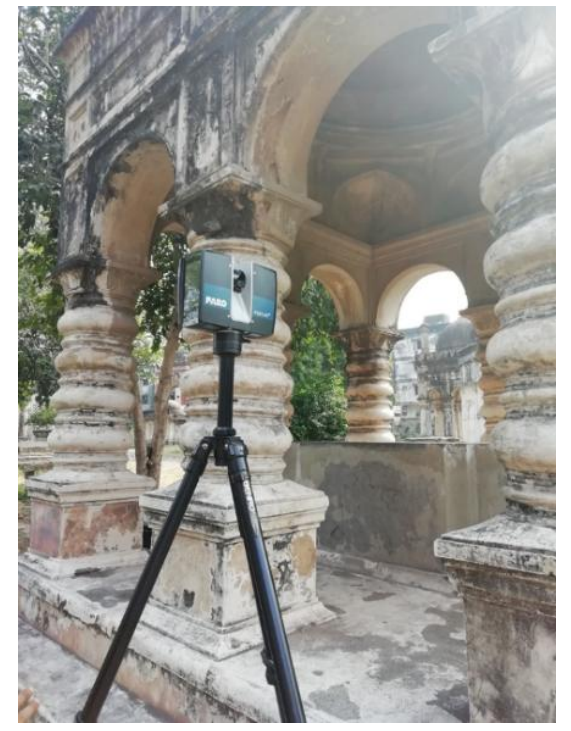

(a) 3D Laser Scanner

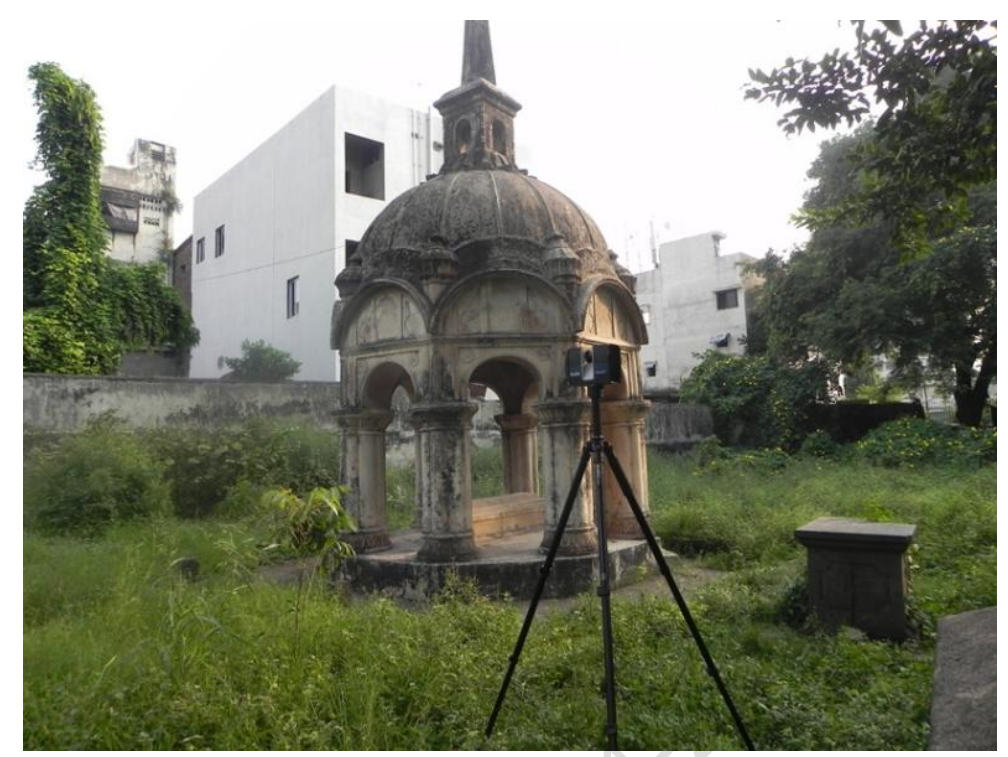

(b) Scanning work in progress

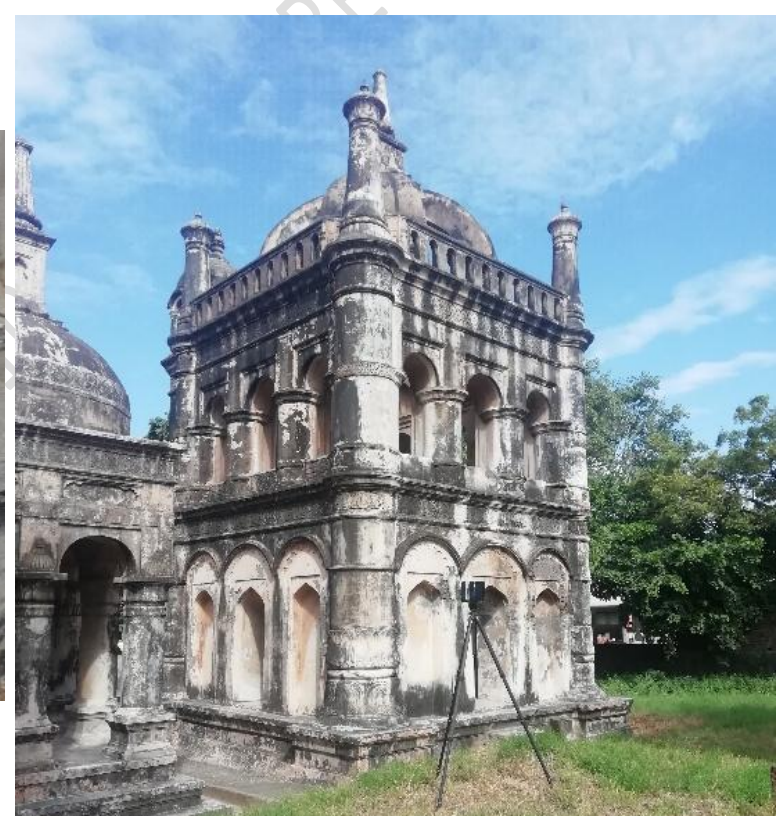

(d) Scanning work on site

Figure 6 Figure showing technologies used in 3D mapping training workshop

\subsubsection{Conservation, preservation, and management}

The heritage structures and monuments are important to be conserved, preserved and managed effectively (Al-Sakkaf et al., 2020). The analysis findings demonstrated how BIM can play a key role towards the conservation, preservation, and management of architectural heritage. This includes the preservation of both tangible and intangible cultural heritage at multiple levels. Stakeholders such as the National Government associations in India, the Archaeological Survey of India, agreed that digitization of heritage structures is an opportunity to conserve tangible and intangible heritage. An 
example is, Oreni (2013) who presented Historic Building Information Modelling (HBIM) based on simplified parametric models for conservation and management of cultural heritage at a macro level. At a micro level, local Government stakeholders such as the Municipal Council emphasized the need for collective platforms that draw all local stakeholders together to support the conservation, preservation and management of heritage (Udeaja et al., 2020). Through this collective platform, the use of digital technologies can be effectively applied (Trillo et al., 2020). As one stakeholder from a heritage charity stated, " to effectively use this (digitsation), we need a participatory approach for heritage conservation". Furthermore as emphasised by national government stakeholders, "policies must be developed for urban conservation and management". These policies should align with local efforts and policies and this symbiotism is not always happening. A repeated suggestion within the workshops was for a decentralised system in India for heritage conservation. In this manner, there is a system of co-responsibility between institutions of governance at the central, regional and local levels. Therefore, supporting the processes of HBIM and any data produced from the digitisation of monuments can be shared effectively at the various stages.

Within the literature, the linkage between HBIM and improved management of heritage conservation practices is frequently suggested and various models and methodologies have been developed by researchers in this regard. The potential impact of BIM for enhanced knowledge management was investigated by Simeone et al. (2014) by means of ontologies. The research by Enrique Nieto et al. (2016) proposed a methodology of management of built heritage by HBIM project with the case study of flooring and wall tiles of heritage buildings. Bruno et al. (2018) proposed diagnosis-aided historic building information modelling and management framework for smart performance assessment of cultural heritage. The study of Megahed (2015) presented a theoretical framework for historic preservation and management by HBIM approach and demonstrated the extent of complexity that can be dealt with HBIM. Acierno et al. (2017) presented ontologybased model for representation and management of information during the conservation of architectural heritage. The potential and methodology of BIM for the management, conservation and preservation of cultural heritage systematically is illustrated by Fassi et al. (2017). The current research and data from the workshops reveal the potential of heritage BIM in terms of effective and efficient management of the architectural heritage precincts.

\subsubsection{Documentation}

Documentation of the architectural heritage is the first priority in any heritage conservation project in order to preserve the data, physical, functional and architectural character of the heritage sites and monuments. The documentation of physical and functional aspects of architectural heritage become easy and efficient with the use of BIM as pointed out by stakeholders. Heritage practitioners identified in the workshop, how the use of digitization for documentation can only be of benefit if there is enough and appropriate data. A further stage beyond documentation was mentioned by a stakeholder in local authority who stated that, "documentation only is not enough and digitization of architectural details of heritage structures should lead to a better story telling of 
heritage." The use of heritage BIM for documentation is supported within the literature. Baik et al. (2015) proposed a framework for documentation of cultural heritage sites based on Jeddah historical building information modelling by integration of 3D BIM and 3D geographic information system (GIS). Soler et al. (2016) presented software for realtime interaction with high-resolution geometric models based complete system of cultural heritage documentation. Cheng et al. (2015) elaborated the potential of laser scanning and photogrammetry for presentation, analysis and archival of heritage documentation. A semi-automatic methodology for documentation of architectural heritage assets using airborne and terrestrial laser scanning data was presented by Kivilcim and Duran (2016). There are several methods available for documentation of cultural heritage. Vandenbulcke et al. (2015) compared the results of laser scanning and the photo modelling for as-built BIM and concluded that both the techniques result into high resolution documentation. Wilson et al. (2018) carried out 3D digital documentation of cultural heritage site for disaster management and immediate decision making in the emergency situation. BIM has proven its capability towards documentation of the architectural heritage which is the permanent digital asset for the concerning authority looking after the monument/site. However, many ongoing researches are focusing on different tools and techniques of documentation of architectural heritage such as advanced photogrammetry and automation of documentation process. The documented digital asset is useful for maintenance, restoration, survey work, virtual modelling, and simulations.

\subsubsection{Maintenance and restoration}

Maintenance and restoration are the primary needs for any architectural heritage in order to prevent and preserve its physical and architectural character. BIM has been extensively used for maintenance management of buildings, green building and new constructed facilities (Ismail, Z.A. 2020). Stakeholders of heritage conservation, particularly those from local authorities, were particularly interested in how digitization and HBIM can be utilized to enhance restoration and maintenance efforts. The maintenance of heritage assets is acknowledged to be a lower priority when compared to other urban development needs. Therefore, with lower budgets, heritage assets can be neglected. Digitization and the use of HBIM can allow for a detailed understanding of areas of need on the heritage assets and by focusing on specific areas this can assist in the prioritization of work. A wide range of BIM applications can be extended for maintenance and restoration of heritage monuments. Maintenance work requires a common platform for various knowledge and information generated by different members of the project team. Motawa and Almarshad (2013) presented a knowledge-based BIM system to integrate all the required knowledge and information as well as the coordination of construction team. Wu et al. (2013) proposed improvement in traditional building repair method by applying 3D laser scanned point cloud BIM model for repairing and maintenance of historical buildings. The renovation and restoration demand smart computer systems as they are very challenging. Smutny (2018) described in detail the systems of building renovations by using BIM. Heritage BIM is the emerging field for 
maintenance and restoration of built heritage which has the huge potential to overcome the deficiencies of the existing practice.

\subsubsection{Virtual technology and Simulation}

A salient theme which emerged from the stakeholder workshops was this need to promote the holistic image of heritage to the communty. The tangible and intangible qualities of heritage should be made accessible to all peoples, especially to the local community. However, this tends to be quite challenging to acheieve on the ground. Different techniques and tools are available to generate a 3D model of architectural heritage, which make it easier to understand and interpret the related attributes of a heritage asset. Apart from the 3D models, the virtual technology is the changing point in this field as it facilitates to visualize the site in the virtual world by different game engines and virtual reality devices. This form of dgital storytelling provides a real world feeling and experience of the site which can allow for improved and increase access to heritage as shown in Figure 7. Rua and Alvito (2011) virtually reconstructed the architectural heritage site and imported into virtual reality (VR) game engine to allow full exploration of the site supported by fauna, flora and artificial intelligence-driven avatars for better visualization of the site in the virtual world. Napolitano et al. (2018) presented virtual tour environments and information modelling workflow and compared it with the conventional 3D documentation. The research of HBIM by Osello et al. (2018) concluded that visualization techniques based on virtual reality and augmented reality are the efficient ways to preserve and consult information about cultural heritage sites. Lin (2017) stated that the integration of HBIM and virtual technology can fulfill the purpose of 3D immersive digital management which gives real experience for the display of cultural heritage. The existing literature point out that the virtual technology is the emerging domain of the digital era of heritage. Virtual technologies have shown a huge potential in developing virtual space to facilitate the real world experience of the heritage sites. Museums and heritage sites are now adopting different virtual technologies to attract more tourists towards the architectural heritage. Refurbishment and conservation projects are also getting huge benefits by using virtual technologies in architectural heritage.

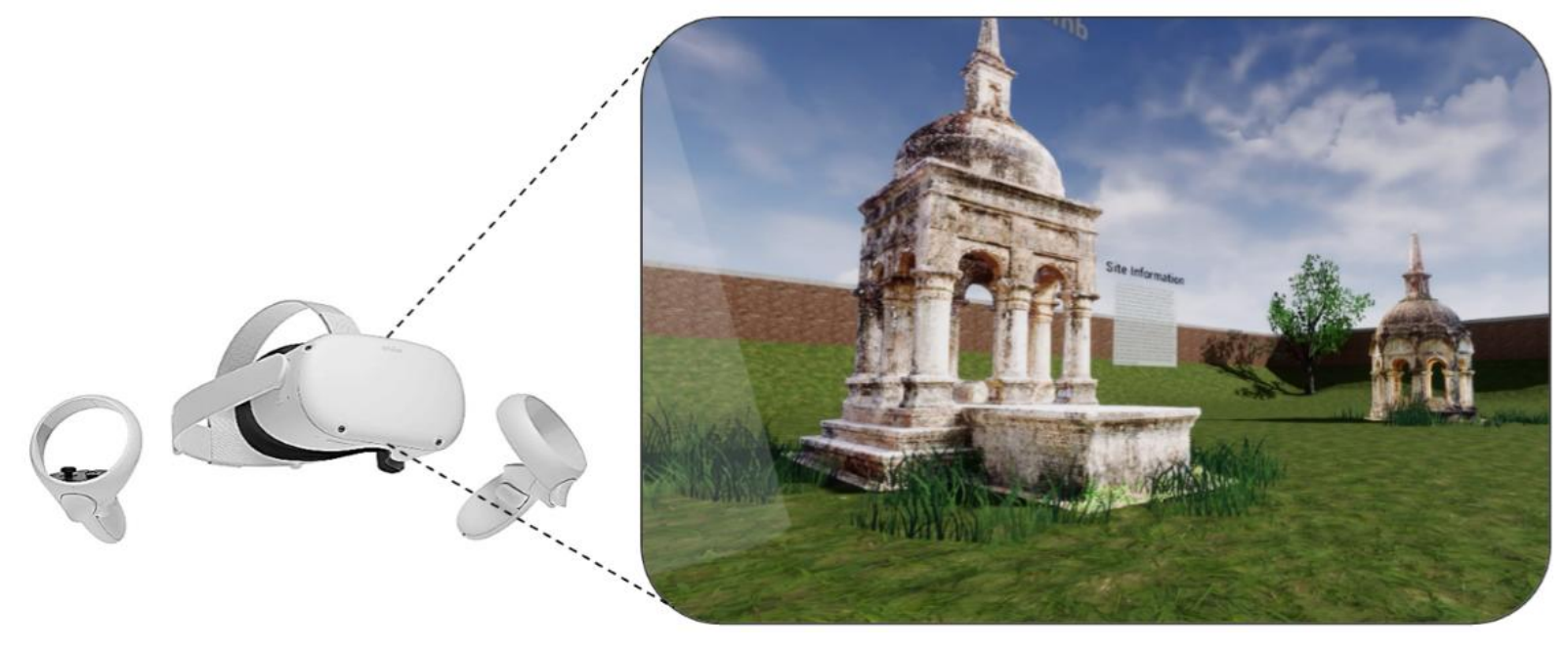


Figure 7 Figure showing the use of virtual reality on a laser scanned heritage monuments

A further advancement is simulation and numerical computation which is the capacity to simulate different conditions and situations of architectural heritage. Barazzetti et al. (2015) presented an innovative methodology which converts historic BIM into a finite element model (FEM) for advanced structural simulations. These simulations can model destructive and non-destructive testings, material behavior, elements behavior and other structural considerations. Structural damage and decay simulations were carried out by Dore et al. (2015) for documentation and conservation analysis using HBIM. Ciocci et al. (2018) carried out structural simulations to evaluate mode shapes, estimate structural performances and investigate the main failure mechanism. Building information modelling was applied for performance, simulation and reformation of design for the old buildings by Lisha et al. (2018). In order to preserve and conserve the heritage structures, simulation plays a strategic role in decision-making process as it gives the simulated condition for different scenarios and situations.

\section{BIM AND HERITAGE RESEARCH PRIORITY RECOMMENDATIONS}

The common research challenges were identified as an integrated outcome of the findings revealed from the scientometric mapping and qualitative review discussed in previous sections. This has resulted in key BIM and heritage research priority recommendations relevant to researchers within this field and presented in this section (Table I).

Table I BIM and heritage research priority recommendations

\begin{tabular}{|c|c|c|c|c|}
\hline Section & $\begin{array}{l}\text { Common } \\
\text { Research } \\
\text { Challenge }\end{array}$ & Research Data & $\begin{array}{c}\text { Key research } \\
\text { priority } \\
\text { recommendation }\end{array}$ & $\begin{array}{c}\text { Future research priority } \\
\text { areas }\end{array}$ \\
\hline 4.1 & $\begin{array}{l}\text { Inadequate } \\
\text { awareness of } \\
\text { the use of } \\
\text { HBIM in } \\
\text { architecture } \\
\text { and heritage } \\
\text { research }\end{array}$ & $\begin{array}{l}\text { - Co-occurring } \\
\text { keyword and } \\
\text { cluster } \\
\text { analysis } \\
\text { - Document co- } \\
\text { citation } \\
\text { analysis } \\
\text { - Journal co- } \\
\text { citation } \\
\text { network } \\
\text { mapping } \\
\text { - Qualitative } \\
\text { study }\end{array}$ & $\begin{array}{l}\text { Emerging } \\
\text { awareness of } \\
\text { HBIM }\end{array}$ & $\begin{array}{l}\text { Developing an } \\
\text { understanding of the } \\
\text { applicability of digital } \\
\text { technologies in } \\
\text { heritage } \\
\text { - Provide funding } \\
\text { opportunities for } \\
\text { HBIM research } \\
\text { - Successful submission } \\
\text { of articles on HBIM in } \\
\text { AEC and heritage } \\
\text { related journals }\end{array}$ \\
\hline
\end{tabular}




\begin{tabular}{|c|c|c|c|c|}
\hline 4.2 & $\begin{array}{l}\text { Limited use } \\
\text { of digital } \\
\text { tools in } \\
\text { HBIM }\end{array}$ & $\begin{array}{l}\text { Document co- } \\
\text { citation } \\
\text { analysis } \\
\text { - Journal co- } \\
\text { citation } \\
\text { network } \\
\text { mapping } \\
\text { - Qualitative } \\
\text { study }\end{array}$ & $\begin{array}{l}\text { Integrating a } \\
\text { variety of digital } \\
\text { tools in HBIM }\end{array}$ & $\begin{array}{l}\text { Assess and evaluate } \\
\text { the use of digital tools } \\
\text { in various heritage } \\
\text { scenarios and in } \\
\text { different contexts } \\
\text { Investigate innovative } \\
\text { strategies of using } \\
\text { digital tools in heritage } \\
\text { such as automation }\end{array}$ \\
\hline 4.3 & $\begin{array}{l}\text { Inadequate } \\
\text { global } \\
\text { collaboration } \\
\text { network }\end{array}$ & $\begin{array}{l}\text { Collaboration } \\
\text { network of } \\
\text { countries } \\
\text { analysis } \\
\text { Journal co- } \\
\text { citation } \\
\text { network } \\
\text { mapping } \\
\text { - Qualitative } \\
\text { study }\end{array}$ & $\begin{array}{l}\text { Build a } \\
\text { framework of } \\
\text { HBIM } \\
\text { collaboration }\end{array}$ & $\begin{array}{l}\text { Assess and address } \\
\text { research policy and } \\
\text { regulatory barriers in } \\
\text { order to facilitate } \\
\text { collaborative working } \\
\text { and sharing of data } \\
\text { Develop international } \\
\text { standards for data } \\
\text { requirements } \\
\text { Reference international } \\
\text { standards for } \\
\text { encouraging } \\
\text { collaborative processes } \\
\text { and sharing of data }\end{array}$ \\
\hline 4.4 & $\begin{array}{l}\text { Lack of } \\
\text { expertise, } \\
\text { skills and } \\
\text { knowledge } \\
\text { on applying } \\
\text { HBIM in } \\
\text { architecture } \\
\text { and heritage } \\
\text { field }\end{array}$ & $\begin{array}{l}\text { Document co- } \\
\text { citation } \\
\text { analysis } \\
\text { - Journal co- } \\
\text { citation } \\
\text { network } \\
\text { mapping } \\
\text { - Qualitative } \\
\text { study }\end{array}$ & $\begin{array}{l}\text { Building } \\
\text { expertise, skills } \\
\text { and knowledge on } \\
\text { HBIM }\end{array}$ & $\begin{array}{l}\text { Develop a skills } \\
\text { framework } \\
\text { - Increase the use of } \\
\text { BIM and other digital } \\
\text { technologies in } \\
\text { university departments }\end{array}$ \\
\hline
\end{tabular}

\subsection{Emerging awareness of HBIM}

The findings discussed in Sections 3, demonstrate an emerging awareness of the use of BIM in the field of architectural heritage. However, at present this awareness is limited to specific areas of research such as: conservation and documentation as well as certain digital tools, mainly laser scanning and photogrammetry. The majority of this research is taking place within a European context. Therefore, there is a need for research on the applicability of BIM in broader areas relating to heritage. Potential areas for future research have been identified from the scientometric mapping in Section 3. These areas include: automated data processing, object recognition, algorithm, free/open source software, automation, restoration and augmented reality. Fields such as accuracy assessment, ontology and decision making are have huge potential for future development. Attention should be given to the influential sources and journals which are the best resource for field practitioners as well as for researchers. 
There is a huge potential of development in the field of augmented reality, Artificial Intelligence (i.e. deep learning, neural network, multi-agent systems, etc.) (Mansuri and Patel, 2021) and object recognition algorithms which can lead to automation in the field of cultural heritage documentation and conservation management using BIM. Further exploration into the development of open source software for research and development purposes can advance future applications of BIM and heritage.

\subsection{Integrating a variety of digital tools in HBIM}

The analysis of HBIM research revealed heavy reliance on two specific tools: laser scanning and photogrammetry. These tools were found to be the most popular tools in research studies. As-built modelling and documentation are mainly done by laser scanning and photogrammetry (Xu et al., 2016). Laser scanning is the most efficient data collection technique for an as-built modelling and reverse engineering, however, the disadvantage of using it is down to the cost of laser scanning tools (Quattrini et al., 2015). There are other tools such as photogrammetry, which uses process of recording, measuring and interpreting photographic images and patterns of electromagnetic radiant imagery and other phenomena to give similar reading output like the laser scanning (Manferdini and Galassi 2013). Researchers from institutions with low resources can use photogrammetry instead of laser scanning because it can be done by using low cost digital cameras. However, they risk long processing times and poor quality in some cases. It is recommended to test these digital tools to enable quick outcomes, cost effectiveness as well as accuracy. More, raw point clouds obtained from laser scanning and photogrammetry needs pre-processing steps like registration, segmentation of data and filtering of noise to generate 3D point cloud that can be used to develop 3D model and HBIM. Generating 3D model from point cloud is still a manual process which requires a lot of time and expertise. This challenge should be further explored in order to make this process automated. Thus, automation in this field is a fertile area for future research (Mansuri and Patel, 2021). Innovative strategies and methodologies should be investigated to enable fast and accurate data collection for HBIM.

\subsection{Build a framework of HBIM collaboration}

The findings suggest that the research linkages and collaborations at a global level are not well established. The main collaborative network exists between European countries such as Italy and countries like the United States and the United Kingdom. This suggests a need for assessing and addressing research policy and regulatory barriers in countries with weak linkages such as global south countries like India, Sri Lanka, Brazil and Mexico and African countries in order to facilitate collaborative working and sharing of data (Udeaja et al., 2020). Furthermore, efforts should be made to develop international standards for data requirements that supports a common understanding and definition of HBIM. Public and private funding agencies and institutions should promote international, inter-institutional and interdisciplinary collaborations among authors and institutions to share their resources, knowledge, experience and expertise for the development of the research area of HBIM. 


\subsection{Building expertise, skills and knowledge on HBIM}

The lack of collaboration with global south countries mentioned in the previous thematic area could indicate a lack of resource, expertise and awareness about the field of HBIM. Therefore, the development of a consistent language and understanding of HBIM according to international standards can form the basis for consistent up-skilling, training and education (Trillo et al. 2020). It is encouraged that guidance material should be developed, explaining the processes of HBIM in diverse contexts, thus encouraging collaborative processes and sharing of data. In most countries it would be cost prohibitive to develop HBIM training courses and materials. Therefore, a recommended research priority is the development of a skill framework which defines the expected learning outcomes which academia and heritage industry can respond to by developing courses and materials which meet this requirement. This skill framework could also act as a driver to increase the use of BIM and other digital technologies in university departments.

\section{CONCLUSIONS}

A mixed method system of scientometric mapping and a qualitative thematic analysis of articles related to HBIM has revealed the hidden potential and opportunities for further development of the field. This study has attempted to explore the emerging domains and latest development in BIM application in architectural heritage field so as to give an overview of the emerging domains and research priorities for researchers in this field. The findings demonstrate the significant potential BIM has in being applied to heritage for diverse reasons. There may be some cases of overlapping between some journals and conference articles in this study. Therefore, future research may use other databases such as Scopus and Google scholar for such kind of mapping.

$\mathrm{BIM}$ is a well-established process to enhance construction and building processes. However, using BIM in heritage conservation is a still a novel opportunity of using BIM in terms of documentation, urban conservation and socio-cultural criteria. Research investigating the values of HBIM particularly in diverse contexts can increase the awareness of the use of BIM in the heritage sector. Therefore, establishing an evidence base can provide future funding opportunities for HBIM multi-disciplinary research. For instance, future research into integration beyond simple intangible details and into the full integration of characteristics such as heritage values and significance that can be embedded into the 3D model in a consistent and structured manner should be considered. Research on HBIM although in its infancy, is largely dominated by Western authors and institutions. This has some implications into how heritage is conceptualised in diverse international and local contexts and should be considered in future research contributions in this area.

\section{References}

Acierno, M., Cursi, S., Simeone, D. and Fiorani, D. (2017), "Architectural heritage knowledge modelling: An ontology-based framework for conservation process", Journal of Cultural Heritage, Vol. 24, pp. 124-133, doi:10.1016/j.culher.2016.09.010 Ahuja, R., Jain, M., Sawhney, A. and Arif, M. (2016), “Adoption of BIM by architectural firms 
in India: technology-organization-environment perspective", Architectural Engineering and Design Management, Vol. 12 No. 4, pp. 311-330, doi: 10.1080/17452007.2016.1186589

Al-Sakkaf, A., Zayed, T., Bagchi, A., Mahmoud, S. and Pickup, D. (2020), "Development of a sustainability rating tool for heritage buildings: future implications", Smart and Sustainable Built Environment, Vol. ahead-of-print No. ahead-of-print, doi: 10.1108/SASBE-04-2020-0047

Anton, D., Medjdoub, B., Shrahily, R. and Moyano, J. (2018), "Accuracy evaluation of the semi-automatic 3D modeling for historical building information models", International Journal of Architectural Heritage, Vol. 12 No. 5, pp. 790-805, doi: 10.1080/15583058.2017.1415391

Arayici, Y. (2008), "Towards building information modelling for existing structures", Structural Survey, Vol. 26 No. 3, pp. 210-222, doi:10.1108/02630800810887108

Baik, A., Yaagoubi, R. and Boehm, J. (2015), "Integration of Jeddah Historical BIM And 3D GIS for Documentation and Restoration of Historical Monument", in Yen, YN and Weng, KH and Cheng, HM (Ed.), 25th international CIPA symposium 2015, vol. 40-5, pp. 29-34, doi: 10.5194/isprsarchives-XL-5-W7-29-2015

Bala S. (2012) Digital inventories on Cultural Memories and Intangible Cultural Heritage: Case study of Yadav community of Haryana, India, available at: http://network.icom.museum/fileadmin/user_upload/minisites/cidoc/Conference Papers/2012/bala.pdf (accessed on 25 September 2020)

Barazzetti, L., Banfi, F., Brumana, R., Gusmeroli, G., Previtali, M. and Schiantarelli, G. (2015), "Cloud-to-BIM-to-FEM: Structural simulation with accurate historic BIM from laser scans", Simulation Modelling Practice and Theory, Vol. 57, pp. 71-87, doi: 10.1016/j.simpat.2015.06.004

Bruno, S., De Fino, M. and Fatiguso, F. (2018), “Historic Building Information Modelling: performance assessment for diagnosis-aided information modelling and management", Automation in Construction, Vol. 86, pp. 256-276, doi: 10.1016/j.autcon.2017.11.009

Carlisle P and Lee E. (2016) "Recording the past: heritage inventories in England", Journal of Cultural Heritage Management and Sustainable Development 6: 128-137, doi: 10.1108/JCHMSD-02-2016-0013

Cheng, H.-M., Yang, W.-B. and Yen, Y.-N. (2015), "BIM applied in historical building documentation and refurbishing", in Yen, YN and Weng, $\mathrm{KH}$ and Cheng, HM (Ed.), 25th International CIPA symposium 2015, Vol. 40-5, pp. 85-90, doi: 10.5194/isprsarchives-XL-5-W7-85-2015

Ciocci, M.P., Sharma, S. and Lourenco, P.B. (2018), "Engineering simulations of a supercomplex cultural heritage building: Ica Cathedral in Peru", Meccanica, Vol. 53 No. 7, SI, pp. 1931-1958, doi: 10.1007/s11012-017-0720-3

Daele KV, Meganck L and Mortier S. (2016) "On data-driven systems and system-driven data: Twenty years of the Flanders heritage inventory", Journal of Cultural Heritage Management and Sustainable Development 6: 153-165, doi: 10.1108/JCHMSD-012016-0004 
Dore, C. and Murphy, M. (2012), "Integration of Historic Building Information Modeling (HBIM) and 3D GIS for recording and managing cultural heritage sites", 2012 18th International Conference on Virtual Systems and Multimedia, IEEE, pp. 369-376, doi: 10.1109/VSMM.2012.6365947

Dore, C. and Murphy, M. (2013), "Semi-Automatic Modelling of Building Facades with Shape Grammars using Historic Building Information Modelling", in Boehm, J and Remondino, $\mathrm{F}$ and Kersten, $\mathrm{T}$ and Fuse, T and GonzalezAguilera, D (Ed.), 3D-ARCH 2013 - 3D Virtual Reconstruction and Visualization of Complex Architectures, Vol. 405-W1, pp. 57-64, doi: 10.5194/isprsarchives-XL-5-W1-57-2013

Dore, C., Murphy, M., McCarthy, S., Brechin, F., Casidy, C. and Dirix, E. (2015), "Structural Simulations and Conservation Analysis - Historic Building Information Model (HBIM)", in GonzalezAguilera, D and Remondino, F and Boehm, J and Kersten, T and Fuse, T (Ed.), 3D-ARCH 2015 - 3D Virtual Reconstruction And Visualization Of Complex Architectures, Vol. 40-5, pp. 351-357, doi: 10.5194/isprsarchives-XL-5-W4-3512015

Elghaish, F., Matarneh, S., Talebi, S., Kagioglou, M., Hosseini, M.R. and Abrishami, S. (2020), "Toward digitalization in the construction industry with immersive and drones technologies: a critical literature review", Smart and Sustainable Built Environment, Emerald Publishing Limited, doi: 10.1108/SASBE-06-2020-0077

Enrique Nieto, J., Jose Moyano, J., Rico, F. and Anton, D. (2016), “Management of Built Heritage via the HBIM Project: A Case Study of Flooring and Wall Tiling", Virtual Archaeology Review, Vol. 7 No. 14, pp. 1-12, doi:10.4995/var.2016.4349

Fassi, F., Fregonese, L., Adami, A. and Rechichi, F. (2017), "BIM System for the Conservation and Preservation of the Mosaics of San Marco in Venice", in Hayes, J and Ouimet, C and Quintero, MS and Fai, S and Smith, L (Ed.), ICOMOS/ISPRS International Scientific Committee on Heritage Documentation (CIPA) 26th International CIPA Symposium - Digital Workflows for Heritage Conservation, Vol. 422, pp. 229-236, doi: 10.5194/isprs-archives-XLII-2-W5-229-2017

Golizadeh, H., Hosseini, M.R., Martek, I., Edwards, D., Gheisari, M., Banihashemi, S. and Zhang, J. (2019), "Scientometric analysis of research on 'remotely piloted aircraft", Engineering, Construction and Architectural Management, Emerald Publishing Limited, doi: 10.1108/ECAM-02-2019-0103

Gursel, I., Sariyildiz, S., Akin, Ö. and Stouffs, R. (2009), "Modeling and visualization of lifecycle building performance assessment", Advanced Engineering Informatics, Elsevier, Vol. 23 No. 4, pp. 396-417, doi: 10.1016/j.aei.2009.06.010

He, Q., Wang, G., Luo, L., Shi, Q., Xie, J. and Meng, X. (2017), "Mapping the managerial areas of Building Information Modeling (BIM) using scientometric analysis", International Journal of Project Management, Elsevier, Vol. 35 No. 4, pp. 670-685, doi: 10.1016/j.ijproman.2016.08.001

Hess, D.J. (1997), Science Studies: An Advanced Introduction, NYU press, ISBN: 9780814735640

Hilal, M., Maqsood, T. and Abdekhodaee, A. (2019), "A scientometric analysis of BIM studies in facilities management", International Journal of Building Pathology and 
Adaptation, Emerald Publishing Limited, doi: 10.1108/IJBPA-04-2018-0035

Historic England. (2017) BIM for Heritage. Developing a Historic Building Information Model In: Bryan SAaP (ed). Swindon, UK: Historic England, available at: (accessed on 12 February 2020)

Ismail, Z.-A. (2020), "Maintenance management practices for green building projects: towards hybrid BIM system", Smart and Sustainable Built Environment, Vol. aheadof-print No. ahead-of-print, doi: 10.1108/SASBE-03-2019-0029

Jung, J., Hong, S., Jeong, S., Kim, S., Cho, H., Hong, S. and Heo, J. (2014), "Productive modeling for development of as-built BIM of existing indoor structures", Automation in Construction, Vol. 42, pp. 68-77, doi: 10.1016/j.autcon.2014.02.021

Kivilcim, C.O. and Duran, Z. (2016), "A Semi-Automated Point Cloud Processing Methodology For 3D Cultural Heritage Documentation", in Halounova, L and Safar, V and Remondino, F and Hodac, J and Pavelka, K and Shortis, $\mathrm{M}$ and Rinaudo, F and Scaioni, M and Boehm, J and RiekeZapp, D (Ed.), XXIII ISPRS Congress, Commission V, Vol. 41, pp. 293-296, doi:10.5194/isprsarchives-XLI-B5-293-2016

Leydesdorff, L. (1998), “Theories of citation?”, Scientometrics, Akadémiai Kiadó, copublished with Springer Science+ Business Media BV, Vol. 43 No. 1, pp. 5-25, doi: 10.1007/BF02458391

Leydesdorff, L. and Milojević, S. (2012), “Scientometrics”, ArXiv Preprint ArXiv:1208.4566, pp. 322-327, available at: https://arxiv.org/ftp/arxiv/papers/1208/1208.4566.pdf (accessed on 12 January 2020)

Lin, Y.-C. (2017), “Application of Integration of HBIM and VR Technology to 3D Immersive Digital Management-Take Han Type Traditional Architecture as an Example", in Hayes, J and Ouimet, C and Quintero, MS and Fai, S and Smith, L (Ed.), ICOMOS/ISPRS International scientific committee on heritage documentation (CIPA) 26th International CIPA Symposium - Digital Workflows for Heritage Conservation, Vol. 422, pp. 443-446, doi:10.5194/isprs-archives-XLII-2-W5-443-2017

Lisha, A., Deng, Y. and Ren, M. (2018), "Structural reconstruction design and performance simulation analysis of old buildings based on BIM", International Journal of Lowcarbon Technologies, Vol. 13 No. 3, pp. 255-259, doi:10.1093/ijlct/cty024

Liu, Z., Lu, Y. and Peh, L.C. (2019), “A Review and Scientometric Analysis of Global Building Information Modeling (BIM) Research in the Architecture, Engineering and Construction (AEC) Industry", Buildings, Multidisciplinary Digital Publishing Institute, Vol. 9 No. 10, p. 210, doi: 10.3390/buildings9100210

Logothetis, S., Karachaliou, E. and Stylianidis, E. (2017), "From OSS CAD to BIM for Cultural Heritage Digital Representation", in Aguilera, D and Georgopoulos, A and Kersten, T and Remondino, F and Stathopoulou, E (Ed.), 3D Virtual Reconstruction and Visualization of Complex Architectures, Vol. 42-2, pp. 439-445, doi:10.5194/isprs-archives-XLII-2-W3-439-2017

Mahon, N.A. and Joyce, C.W. (2015), "A bibliometric analysis of the 50 most cited papers in cleft lip and palate", Journal of Plastic Surgery and Hand Surgery, Taylor \& Francis, Vol. 49 No. 1, pp. 52-58, doi: 10.3109/2000656x.2014.951053

Manferdini, A.M. and Galassi, M. (2013), “Assessments for 3D Reconstructions of Cultural 
Heritage using Digital Technologies", in Boehm, J and Remondino, F and Kersten, T and Fuse, T and GonzalezAguilera, D (Ed.), 3D-ARCH 2013 - 3D Virtual Reconstruction and Visualization of Complex Architectures, Vol. 40, pp. 167-174, doi:10.5194/isprsarchives-XL-5-W1-167-2013

Mansuri, L.E. and Patel, D.A. (2021), "Artificial intelligence-based automatic visual inspection system for built heritage", Smart and Sustainable Built Environment, Vol. ahead-of-print No. ahead-of-print, doi:10.1108/SASBE-09-2020-0139

Megahed, N.A. (2015), "Towards A Theoretical Framework for HBIM approach in Historic Preservation and Management", International Journal of Architectural Research, Vol. 9 No. 3, SI, pp. 130-147, doi: 10.26687/archnet-ijar.v9i3.737

Motawa, I. and Almarshad, A. (2013), "A knowledge-based BIM system for building maintenance", Automation in Construction, Vol. 29, pp. 173-182, doi: 10.1016/j.autcon.2012.09.008

Murphy, M., McGovern, E. and Pavia, S. (2009), "Historic building information modelling (HBIM)", Structural Survey, Emerald Group Publishing Limited, doi: 10.1108/02630800910985108

Murphy, M., McGovern, E. and Pavia, S. (2013), "Historic Building Information Modelling - Adding intelligence to laser and image based surveys of European classical architecture", ISPRS Journal of Photogrammetry and Remote Sensing, Vol. 76 No. SI, pp. 89-102, doi:10.1016/j.isprsjprs.2012.11.006

Myers D. (2016) "Heritage inventories: promoting effectiveness as a vital tool for sustainable heritage management", Journal of Cultural Heritage Management and Sustainable Development 6: 102-112, doi: 10.1108/JCHMSD-02-2016-0009

Napolitano, R.K., Scherer, G. and Glisic, B. (2018), "Virtual tours and informational modeling for conservation of cultural heritage sites", Journal of Cultural Heritage, Vol. 29, pp. 123-129, doi:10.1016/j.culher.2017.08.007

Olawumi, T.O. and Chan, D.W.M. (2018), "A scientometric review of global research on sustainability and sustainable development", Journal of Cleaner Production, doi: 10.1016/j.jclepro.2018.02.162

Oreni, D. (2013), "From 3D Content Models to HBIM for Conservation and Management of Built Heritage", in Murgante, B and Misra, S and Carlini, M and Torre, CM and Nguyen, HQ and Taniar, D and Apduhan, BO and Gervasi, O (Ed.), Computational Science and its Applications - ICCSA 2013, PT IV, Vol. 7974, pp. 344-357, doi: 10.1007/978-3-642-39649-6_25

Osello, A., Lucibello, G. and Morgagni, F. (2018), "HBIM and Virtual Tools: A New Chance to Preserve Architectural Heritage", Buildings, Vol. 8 No. 1, doi: 10.3390/buildings8010012.

Petti L, Trillo C and Makore BN. (2020) "Cultural Heritage and Sustainable Development Targets: A Possible Harmonisation? Insights from the European Perspective", Sustainability 12, doi: 10.3390/su12030926

Quattrini, R., Malinverni, E.S., Clini, P., Nespeca, R. and Orlietti, E. (2015), "From TLS to HBIM. High Quality Semantically-Aware 3d Modeling of Complex Architecture", in GonzalezAguilera, D and Remondino, F and Boehm, J and Kersten, T and Fuse, T (Ed.), 
3D-ARCH 2015 - 3D Virtual Reconstruction and Visualization of Complex Architectures, Vol. 40-5, pp. 367-374, doi:10.5194/isprsarchives-XL-5-W4-367-2015

Rocha G, Mateus L, Fernández J, et al. (2020) “A Scan-to-BIM Methodology Applied to Heritage Buildings", Heritage 3: 47-65, doi: 10.3390/heritage3010004

Rodriguez-Gonzalvez, P., Luis Munoz-Nieto, A., del Pozo, S., Sanchez-Aparicio, L.J., Gonzalez-Aguilera, D., Micoli, L., Barsanti, S.G., et al. (2017), "4D Reconstruction and Visualization of Cultural Heritage: Analyzing our Legacy Through Time”, in Aguilera, D and Georgopoulos, A and Kersten, T and Remondino, F and Stathopoulou, E (Ed.), 3D Virtual Reconstruction and Visualization of Complex Architectures, Vol. 42-2, pp. 609-616, doi:10.5194/isprs-archives-XLII-2-W3-609-2017

Rojas-Sola, J.I. and de la Morena-de la Fuente, E. (2018), "Digital 3D Reconstruction of Betancourt's Historical Heritage: The Dredging Machine in the Port of Kronstadt", Virtual Archaeology Review, Vol. 9 No. 18, pp. 44-56, doi: doi:10.4995/var.2018.7946 Rua, H. and Alvito, P. (2011), "Living the past: 3D models, virtual reality and game engines as tools for supporting archaeology and the reconstruction of cultural heritage - the case-study of the Roman villa of Casal de Freiria", Journal of Archaeological Science, Vol. 38 No. 12, pp. 3296-3308, doi:10.1016/j.jas.2011.07.015

Shah K. (2016) "Creation of cultural heritage inventories: case of the historic city of Ahmadabad", Journal of Cultural Heritage Management and Sustainable Development 2: 166-194, doi: 10.1108/JCHMSD-02-2016-0011

Simeone, D., Cursi, S., Toldo, I. and Carrara, G. (2014), "BIM and Knowledge Management for Building Heritage", in Gerber, D and Huang, A and Sanchez, J (Ed.), ACADIA 2014: Design Agency, USC School of Architecture, pp. 681-690, available at: http://papers.cumincad.org/data/works/att/acadia14_681.content.pdf (accessed on $16 / 07 / 2019)$

Small, H.G. (1978), "Cited documents as concept symbols”, Social Studies of Science, Sage Publications Sage CA: Thousand Oaks, CA, Vol. 8 No. 3, pp. 327-340, doi: 10.1177/030631277800800305

Smutny, M. (2018), "Building renovations in BIM systems", in Senitkova, IJ (Ed.), 9th International Scientific Conference Building Defects (Building Defects 2017) Vol. 146, doi: $10.1051 /$ matecconf/201814601006.

Soler, F., Melero, F.J. and Luzón, M.V. (2016), “A complete 3D information system for cultural heritage documentation", Journal of Cultural Heritage, Vol. 23, pp. 49-57, doi: doi:10.1016/j.culher.2016.09.008

Tang, P., Huber, D., Akinci, B., Lipman, R. and Lytle, A. (2010), “Automatic reconstruction of as-built building information models from laser-scanned point clouds: A review of related techniques", Automation in Construction, Elsevier, Vol. 19 No. 7, pp. 829-843, doi:10.1016/j.autcon.2010.06.007

Trillo, C., Aburamadan, R., Udeaja, C., Moustaka, A., Baffour, K.G. and Makore, B.C.N., (2020) "Enhancing heritage and traditional architecture conservation through digital technologies. Developing a digital conservation handbook for As-Salt, Jordan" In International Symposium: New Metropolitan Perspectives, pp. 211-219, doi: 10.1007/978-3-030-52869-0_18 
Udeaja, C., Trillo, C., Awuah, K.G.B., Makore, B.C.N., Patel, D.A., Mansuri, L.E. and Jha, K.N. (2020), "Urban heritage conservation and rapid urbanization: insights from Surat, India”, Sustainability, Vol. 12 No. 6, p. 2172, doi: 10.3390/su12062172.

UN-Habitat. (2018) Metadata on SDGs Indicator 11.4.1 Indicator category: Tier III. Kenya: United nations human settlements program (UN-Habitat).

United Nations. (2016) Sustainable Development Goals, available at: http://www.un.org/sustainabledevelopment/sustainable-developmentgoals/.(accessed on 25 September 2020)

Vandenbulcke, A., De Wulf, A., Stal, C., Goossens, R. and Deruyter, G. (2015), “Comparison of Terrestrial Laser Scanning and Photo Modelling for the Documentation of Cultural Heritage", Informatics, Geoinformatics and Remote Sensing, Vol I, pp. 1227-1234, http://hdl.handle.net/1854/LU-6897098

Vilutiene, T., Kalibatiene, D., Hosseini, M.R., Pellicer, E. and Zavadskas, E.K. (2019), "Building information modeling (bim) for structural engineering: a bibliometric analysis of the literature", Advances in Civil Engineering, Hindawi, Vol. 2019, doi: $10.1155 / 2019 / 5290690$

Volk, R., Stengel, J. and Schultmann, F. (2014), "Building Information Modeling (BIM) for existing buildings - Literature review and future needs", Automation in Construction, Vol. 38, pp. 109-127, doi:10.1016/j.autcon.2013.10.023

Wilson, L., Rawlinson, A., Frost, A. and Hepher, J. (2018), “3D digital documentation for disaster management in historic buildings: Applications following fire damage at the Mackintosh building, The Glasgow School of Art", Journal of Cultural Heritage, Vol. 31, pp. 24-32, doi: doi:10.1016/j.culher.2017.11.012

Wu, T.C., Lin, Y.C., Hsu, M.F., Zheng, N.W. and Chen, W.L. (2013), “Improving Traditional Building Repair Construction Quality using Historic Building Information Modeling Concept", in Grussenmeyer, P (Ed.), XXIV International CIPA Symposium, Vol. 40-5W2, pp. 691-694, doi:10.5194/isprsarchives-XL-5-W2-691-2013

$\mathrm{Xu}, \mathrm{Z} ., \mathrm{Wu}$, L., Shen, Y., Li, F., Wang, Q. and Wang, R. (2014), “Tridimensional Reconstruction Applied to Cultural Heritage with the Use of Camera-Equipped UAV and Terrestrial Laser Scanner", Remote Sensing, Vol. 6 No. 11, pp. 10413-10434, doi:10.3390/rs61110413

$\mathrm{Xu}, \mathrm{Z}$., Wu, T.H., Shen, Y. and Wu, L. (2016), "Three Dimentional Reconstruction of Large Cultural Heritage objects based on UAV Video And TLS Data", in Halounova, L and Safar, V and Remondino, F and Hodac, J and Pavelka, K and Shortis, M and Rinaudo, $\mathrm{F}$ and Scaioni, M and Boehm, J and RiekeZapp, D (Ed.), XXIII ISPRS Congress, Commission V, Vol. 41, pp. 985-988, doi:10.5194/isprsarchives-XLI-B5-985-2016

Zhao, X. (2017), "A scientometric review of global BIM research: Analysis and visualization", Automation in Construction, Vol. 80, pp. 37-47, doi:10.1016/j.autcon.2017.04.002 